\title{
Pseudomeriones hansi nov. sp. (Rodentia, Mammalia) from the Early Pliocene (Ruscinian) Fauna of Iğdeli (Turkey)
}

\author{
Fadime Suata-Alpaslan ${ }^{*}$ \\ Cumhuriyet University, Faculty of Science and Letters, Anthrophology Department, 58140, Sivas, Turkey
}

\begin{abstract}
Pseudomeriones hansi nov. sp. is described from İğdeli locality (SW Sivas, Central Anatolia). The morphological description of the new species is given within its own systematic and stratigraphic relationships. The micromammalian fauna of İğdeli gives evidence for a new species which is characterized by its small size, its M2 with a deep lingual sinus curved backward and its $\mathrm{m} 1$ with a symmetric triangular anteroconid that bears a moderate labial arm reaching the base of the protoconid.
\end{abstract}

Keywords: Iğdeli, Early Pliocene/Ruscinian, Mammalia, Pseudomeriones, Taxonomy, Biocronology.

\section{INTRODUCTION}

İğdeli is situated in the southwestern of Sivas city (Central Anatolia, Turkey), (Fig. 1). Small mammals from the İğdeli have been collected during the recent geological projects of the M.T.A. (General Directorate of Mineral Research and Exploration, Turkey). The material has been found in fine grain sediments below lacustrine limestones of the upper part of the Eğerci formation (Gemerek, Sivas) [1]. The assemblage of micromammals is quite varied, and consists of sixteen species of rodents (Promimomys insuliferus, Apodemus dominans, Occitanomys (Rhodomys) vandami n. sp., Micromys bendai, Muridae gen. et sp. indet., Cricetus cf. lophidens, Mesocricetus cf. primitivus, Cricetulus migratorius, Allocricetus bursae, Kowalskia sp., Cricetidae indet., Myomimus igdeliensis n. sp., Tamias sp., Keramidomys cf. carpathicus, Pseudomeriones hansi n. sp., Spalacidae gen. et sp. indet.) and two species of lagomorphs (Ochotona mediterranensis n. sp., Prolagus sp.). The occurrence of Promimomys insuliferus in İğdeli locality suggests an Early Pliocene/Early Ruscinian (MN 14) age.

\section{MATERIAL AND METHODS}

The rodent teeth described below have been collected by wet-screening material from İğdeli locality. The mesh of the finest sieve used is $0.5 \mathrm{~mm}$. The approximate weight of the matrix washed from the locality was $3000 \mathrm{~kg}$. The residues obtained after washing have been sorted by using a microscope. The maximum lengths of the murid cheek teeth have been measured from front to back whereas the maximum widths have been taken in the labial to lingual sense. The teeth were measured with a Nikon measuroscope. Measurements (length X width) are given in millimeters in the table. The teeth are all figured by magnified by 20 .

The teeth terminology used here follows [2]. İğdeli material has been stored in the collections of the General Directorate of Mineral Research and Exploration (M.T.A.) in Ankara.

*Address correspondence to this author at the Cumhuriyet University, Faculty of Science and Letters, Anthrophology Department, 58140, Sivas, Turkey; E-mail: fsalpaslan@yahoo.com.tr

\section{SYSTEMATICS}

Mc. Kenna \& Bell 1997

Ordo Rodentia Bowdich, 1821

Family Muridae Gray, 1821

Sub-Family Gerbillinae, Gray, 1825

Genus Pseudomeriones Schaub, 1934

Pseudomeriones hansi n. sp.

(Plate I, Figs. 6-18)

Type locality: İ̆gdeli

Type Level: Early Pliocene/Early Ruscinian

Holotype: Left M2 (Plate I, Fig. 13, İĞ. 72)

Derivatio nominis: The name is dedicated to Dr. Hans de Bruijn due to his cherished contributions to the works on small mammals in Turkey.

Diagnosis: Pseudomeriones of small size; M1 has threefour roots and M2 has two-three roots. The length/width ratio of $\mathrm{M} 1$ and of $\mathrm{m} 1$ is approximately 1.59 and 1.60 respectively (Table 1). M2 has a deep lingual sinus. $\mathrm{m} 1$ has a symmetric triangular anteroconid which has a moderate labial arm reaching to the base of the protoconid.

Differential diagnosis: $P$. hansi n. sp. differs from $P$. rhodius and $P$. tchaltaensis in the smaller ratio of length to width for M1 and $\mathrm{m} 1$, wider M1 than $\mathrm{m} 1$ (Table 1, Figs. 35), and in the presence of a posterior lingual sinus (or syncline) on M2 that is curved backwards. It also differs from $P$. tchaltaensis in the lower crowned molars.

When it comes to compare $P$. hansi with $P$. megistos, the latter is significantly larger than the former, and lacks the posterolophid on its $\mathrm{m} 1$. $P$. hansi also differs from $P$. complicidens in being much higher and in terms of morphology, M2 with a deep lingual sinus curved backward and $\mathrm{M} 1$ and $\mathrm{m} 2$ with much less developed posterolophids than those of $P$. complicidens.

$P$. hansi differs from $P$. abbreviatus, $P$. latidens and $P$. pythagorasi in the larger width/length ratio of both M1 and 


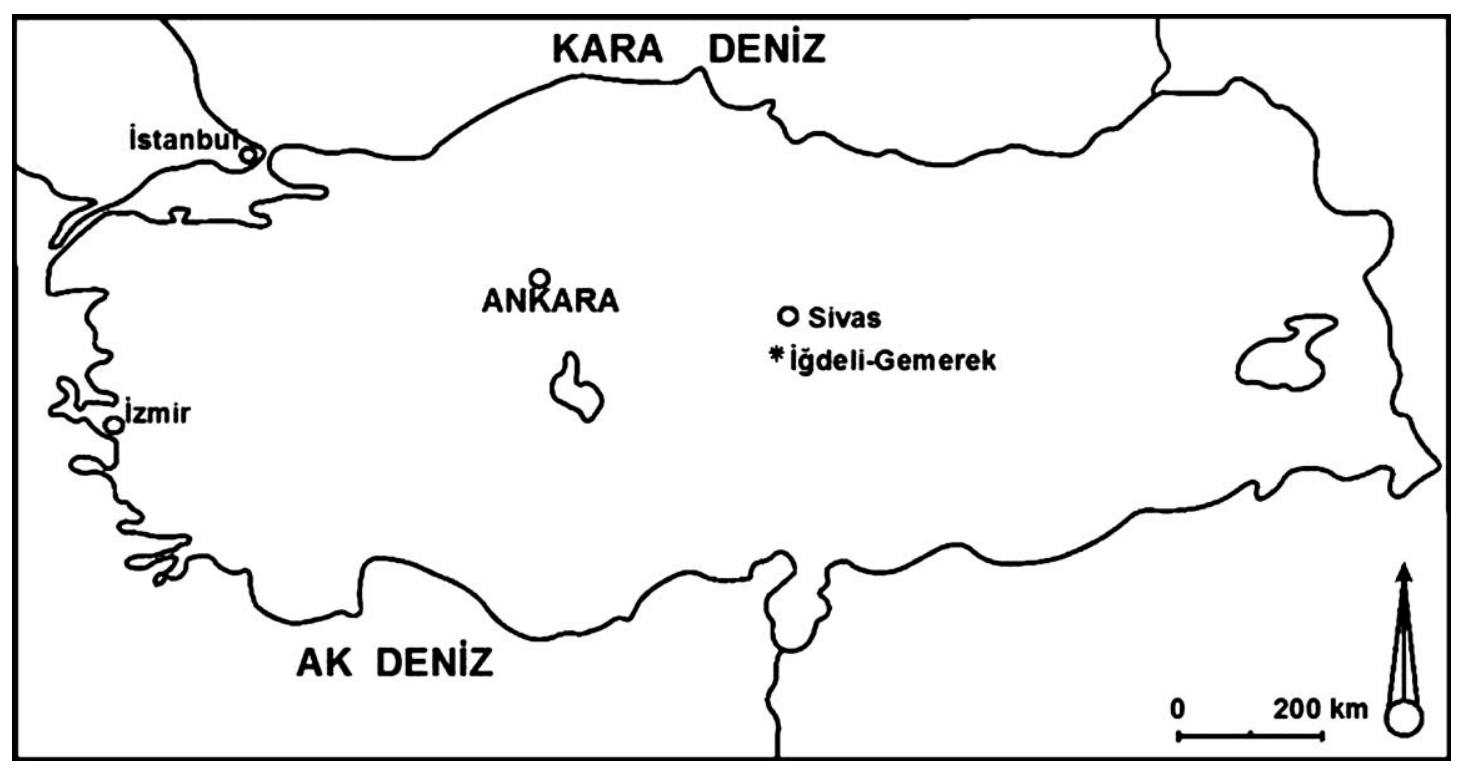

Fig. (1). Sketch map showing the approximate positions of the Early Pliocene locality of İğdeli, Eastern Mediterrenean. * İğdeli (Gemerek, Sivas)

$\mathrm{m} 1$ and the more elongated, symmetric and triangular shaped anteroconid. $P$. hansi further differs from $P$. latidens in the shallower protosinusid on $\mathrm{m} 2$, the weaker anterolabial cusp on $\mathrm{m} 3$, in M2 the lower occurrence frequency of the anteroloph which if present is more weakly developed. Moreover, $P$. hansi doesn't have the labial anterolophid on m3 unlike $P$. latidens.

\section{MATERIAL AND MEASUREMENTS}

\begin{tabular}{|c|c|c|c|c|c|}
\cline { 2 - 6 } \multicolumn{1}{c|}{} & \multicolumn{2}{c|}{ Length } & & \multicolumn{2}{c|}{ Width } \\
\cline { 2 - 6 } \multicolumn{1}{c|}{} & Range & Mean & $\mathrm{N}$ & Range & Mean \\
\hline m1 & $19.75-23.90$ & 21.57 & 16 & $11.00-15.30$ & 13.34 \\
\hline m2 & $13.25-16.25$ & 14.40 & 13 & $12.50-14.00$ & 13.10 \\
\hline m3 & $8.10-10.25$ & 8.82 & 5 & $9.40-10.90$ & 10.32 \\
\hline M1 & $21.50-25.00$ & 23.90 & 6 & $11.00-14.50$ & 13.84 \\
\hline M2 & $11.00-16.00$ & 12.59 & 15 & $11.50-15.00$ & 13.36 \\
\hline M3 & $7.50-9.00$ & 8.25 & 2 & $10.00-11.00$ & 10.50 \\
\hline
\end{tabular}

Description: $\mathrm{m} 1-3$ is mandibular teeth and M1-3 is maxillary teeth.

The cricetid form on M1, M2, m1 and m2 is clearly seen.

$\mathrm{m} 1$. Lower $\mathrm{m} 1$ is narrow and long. The main cuspids are alternated with one another. Anteroconid is triangle, quite symmetrical, wide and anteriorly elongated in shape. It has a moderate labial cingulum reaching to the base of the protoconid. Metalophid and hypolophid are paralell to each other, slightly curv backwards and attach to the labial cuspids at the front. The posterolophid is seperated from the entoconid through with a relatively deep posterior lingual sinusid in eleven out of fifteen samples, it is very short in other two samples, while in the rest two it looks like a projection (crest-like) in the posterior side. Generally, the samples with less developed or non-developed posterolophids belong to the old individuals. The $\mathrm{m} 1$ is two rooted, having one anterior and one posterior roots.

$\mathrm{m} 2 . \mathrm{m} 2$ is square in shape. The main cuspids are alternated with one another. Twelve out of thirteen samples have two labial sinusids; the anterior one is shallow and the other one forms a deep lingual sinusid curved forward. In the other tooth which is less worn out, there is a clear additional, shallow postero-lingual sinusid. So, the posterolophid in the mentioned tooth has been significantly developed whereas in most of the teeth, it forms just a projection in the posterior loph. The depth of the anterior labial sinusid is variable. In four samples, the anterior labial sinusid is quite deep, suggesting that it is not related with corrosion and it is similar to the cricetid pattern in shape. $\mathrm{m} 2$ has one anterior and one posterior root.

$\mathrm{m} 3$. It is asymmetric V shaped and consists of one lingual sinusid. $\mathrm{m} 3$ is two rooted with one anterior and one posterior roots.

M1. The occlusal surface is quite narrow and long. The main cusps are alternated with one another. The anterocone is quite developed though narrower than the posterior lophs. In nine samples out of seventeen, M1 has three roots but in the rest eight samples a very little fourth root occurs in the labial side below the paracone.

M2. It consists of two lophs almost equal in mass. There is a lingual and a labial sinus. The lingual sinus is curved backwards and it is deeper than the labial. The anteroloph is apparent in one of fourteen samples and in the others, it is either quite weak or absent. M2 has three roots in ten samples and four in fourteen samples.

M3. The occlusal surface is a symmetrical and closed Vshaped. The posterior loph is smaller than the anterior. The lingual sinus is quite deep. M3 has three roots. 
Table 1. The Length/Width Ratios of the Molars of Pseudomeriones Species

\begin{tabular}{|c|c|c|c|c|c|c|c|}
\hline Species & Locality & m1 & $\mathbf{m} 2$ & m3 & M1 & M2 & M3 \\
\hline P. tchaltaensis & Çalta & 1.74 & 1.09 & 1.10 & 1.79 & 0.93 & 0.84 \\
\hline P. megistos & Paliambela-B and Monasteri & 1.52 & 1.09 & - & 1.70 & 0.86 & - \\
\hline P. complicidens & Ningxian & 2.00 & 1.16 & - & - & - & - \\
\hline \multirow{2}{*}{ P. rhodius } & Maritsa & 1.71 & 0.97 & 1.01 & 1.81 & 0.88 & 0.88 \\
\hline & Develi & 1.79 & --- & 0.89 & -- & 0.93 & --- \\
\hline P. hansi & İğdeli & 1.60 & 1.09 & 0.85 & 1.59 & 0.94 & 0.83 \\
\hline \multirow{2}{*}{ P. abbreviatus } & King-Yan-fou (Kansu) & 1.52 & 1.07 & 1.12 & 1.76 & 1.04 & 0.89 \\
\hline & Pul-e Charkii & 1.41 & 1.00 & 0.88 & 1.51 & 0.92 & 0.77 \\
\hline P. pythagorasi & Samos & 1.54 & -- & -- & 1.43 & -- & -- \\
\hline \multirow{4}{*}{ P. latidens } & Molayan & 1.52 & 1.02 & 0.95 & 1.48 & 0.95 & 0.79 \\
\hline & Karaözü & 1.54 & 1.03 & -- & 1.47 & 0.95 & 0.78 \\
\hline & Dendil & 1.50 & 1.07 & 0.97 & 1.44 & 0.98 & 0.91 \\
\hline & Kaleköy & 0.97 & -- & --- & --- & 0.91 & --- \\
\hline
\end{tabular}

\section{REMARKS}

İğdeli gerbil with its "cricetid" structure of cusp/cuspid alternation on $\mathrm{m} 1 / \mathrm{M} 1$ and the presence of two labial and one lingual sinusids on $\mathrm{m} 2$ clearly shows the characteristic features of Pseudomeriones. Historical overviews of the genus are given by [2-10].
The most primitive type of Pseudomeriones is $P$. latidens, firstly described from Molayan, Afghanistan (MN13) $[11,12]$. Older representatives of $P$. latidens have been found in Karaözü, Kaleköy and Dendil (Turkey) which are placed in the MN 9-11 zones in Anatolia [8, 12, 13, 21]. If Karaözü, Kaleköy and Dendil are older than Molayan, then $P$. latidens must have been migrated to Afghanistan and

\section{P. tchaltaensis}

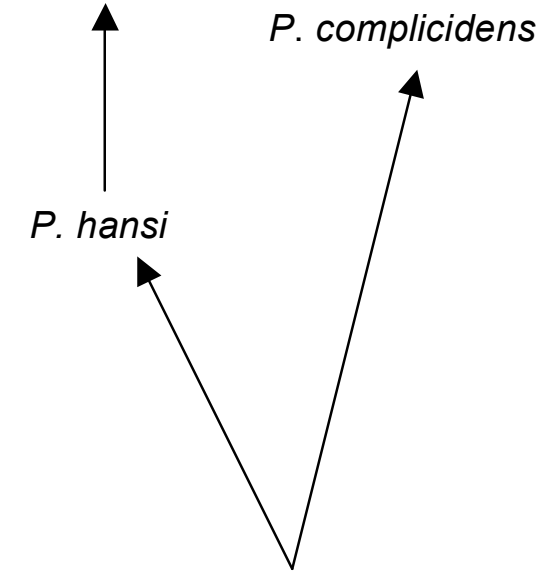

P. abbreviatus

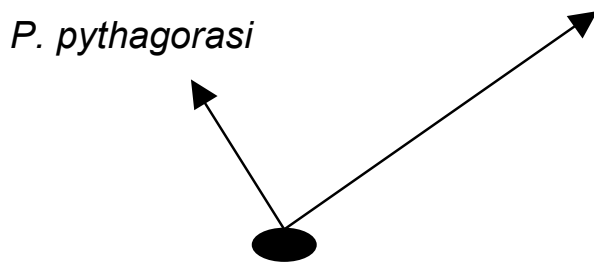

\section{P. latidens}

Fig. (2). Scenario of ancestor-descendant relationships of several Pseudomeriones species (adopted from Sylvestrou \& Kostopoulos 2007). 

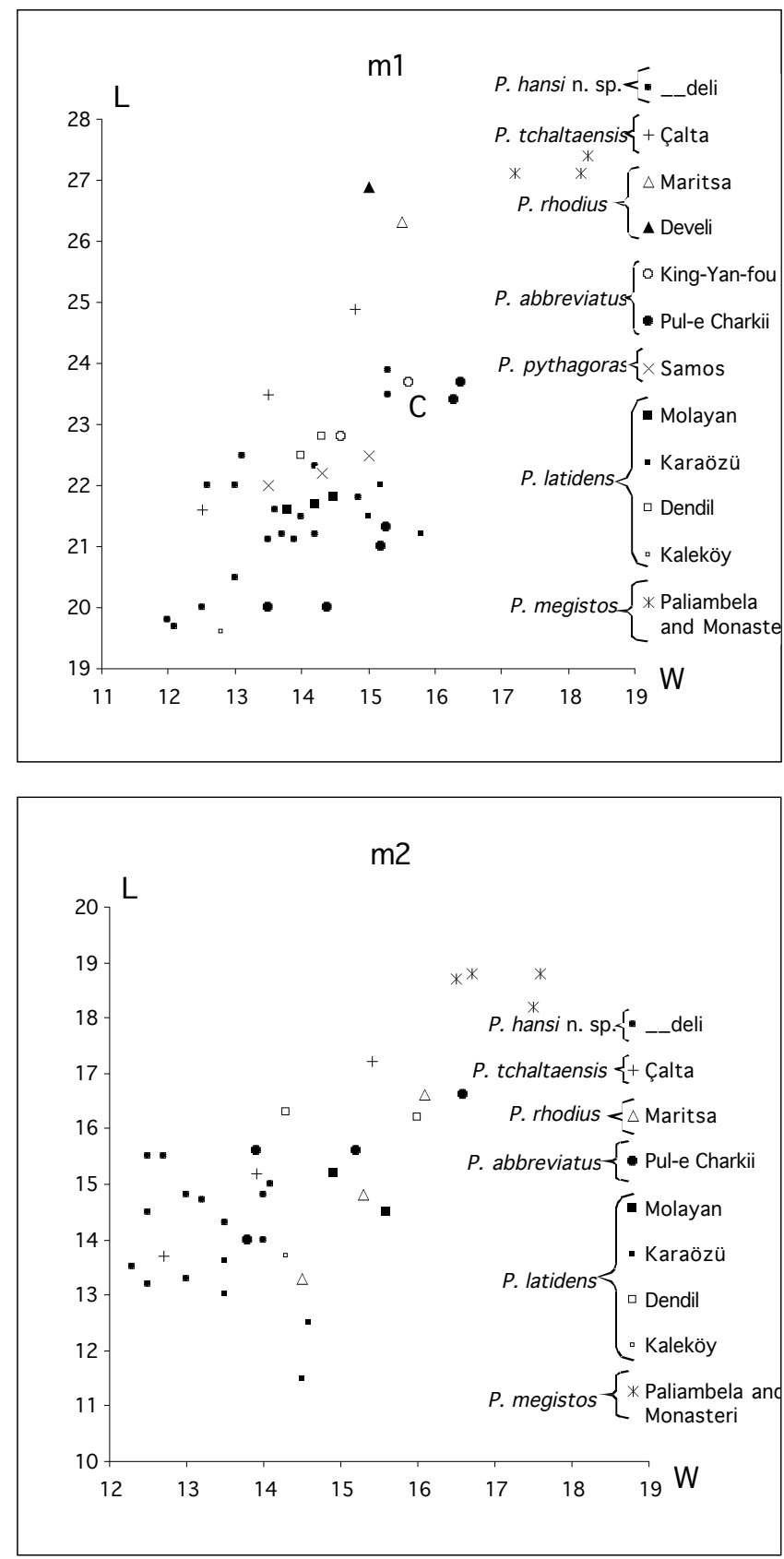

Fig. (3). Length-width scatter diagrams of $\mathrm{m} 1$ and $\mathrm{m} 2$ of Pseudomeriones species from different localities.

China from Anatolia and evolved firstly into P. abbreviatus $[14,15]$ which [4], evolved into $P$. complicidens later in China [20]. In Anatolia, P. latidens must have evolved into $P$. rhodius [16] and $P$. megistos [10] through $P$. pythagorasi [17] and into $P$. tchaltaensis through $P$. abbreviatus and then $P$. hansi [10] (Fig. 2). Evolutionary trends inside the genus are towards the increase in the height of the crown, the length and symmetry of anteroconid of $\mathrm{m} 1$, the decrease in the width of M1 and $\mathrm{m} 1$ and the strength of the labial arm of anteroconid, the size of posterolophid, the width of anterolabial sinusid on $\mathrm{m} 2$ and the number of roots in $\mathrm{m} 2$ (two). This evolutionary scenario complies with the observation of [6] too, except the fact that its $P$. rhodius [3, $18,19]$ consists of only three rooted M2-morphotypes. It
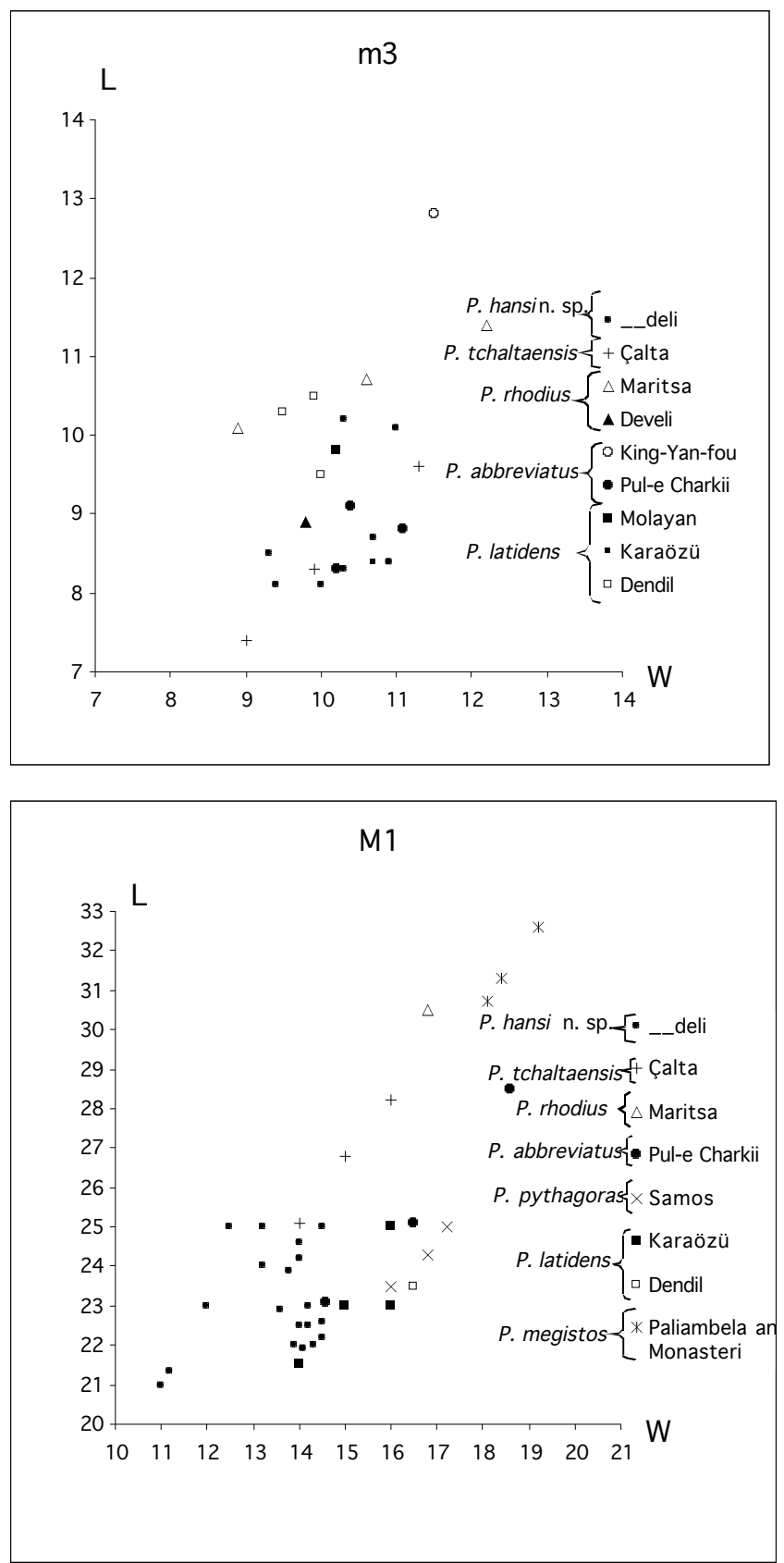

Fig. (4). Length-width scatter diagrams of $\mathrm{m} 3$ and $\mathrm{M} 1$ of Pseudomeriones species from different localities.

should be noted that $P$. latidens of Dendil shows two rooted morphotypes as well [13], suggesting a more advanced form than İğdeli species. Morphologically $P$. rhodius is almost as much developed as $P$. tchaltaensis because the crowns of the teeth of Çalta species are as high as those of $P$. rhodius, their $\mathrm{M} 1$ and $\mathrm{m} 1$ are narrow and their anteroconid is strong, the mezosinus of $\mathrm{M} 2$ is deep and the protosinusid of $\mathrm{m} 2$ is shallow.

\section{DISCUSSION AND CONCLUSIONS}

The study of the Pseudomeriones (Rodentia) material from İğdeli (Central Anatolia, Turkey) validates the presence of a new species, $P$. hansi, characterized by the length/ width ratio of M1 and of $\mathrm{m} 1$ (1.59 and 1.60 respectively). The M2 

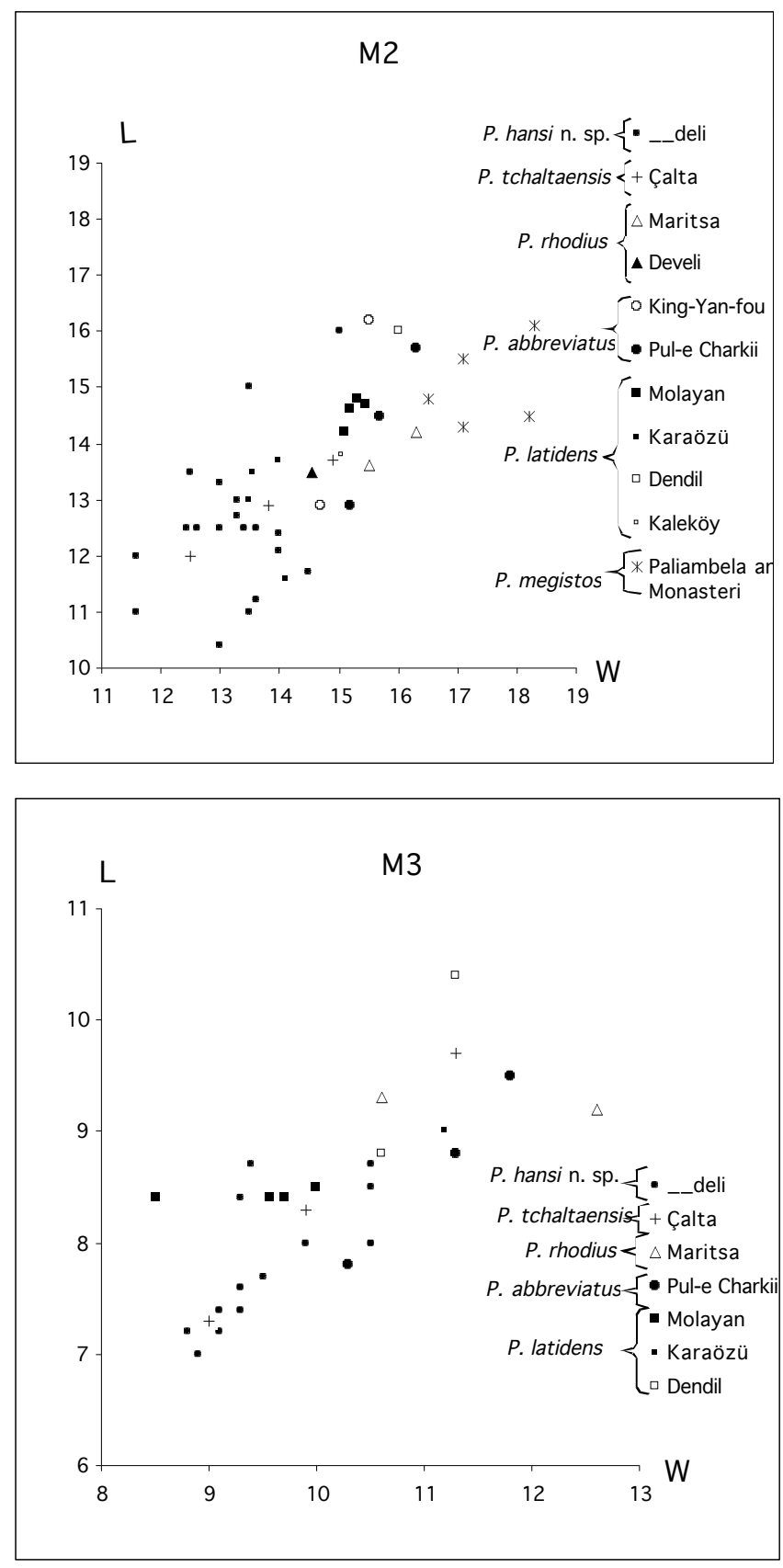

Fig. (5). Length-width scatter diagrams of $\mathrm{M} 2$ and $\mathrm{M} 3$ of Pseudomeriones species from different localities.

has a deep lingual sinus. $\mathrm{m} 1$ has a symmetric triangular anteroconid with a moderate labial arm reaching to the base of the protoconid. A phylogenetic analysis based on dental characters emphasizes close relationships among the Pseudomeriones species. According to the suggested evolutionary scenario, these species originated from population of $P$. latidens. $P$. hansi clade, originated from the same ancestral stock, led to the widely distributed Late Turolian P. abbreviatus, which, in its turn, splits during Ruscinian into two geographic lineages: a West Asian one represented by $P$. hansi and its possible descendant $P$. tchaltaensis and an East Asian one that led to $P$. complicidens [10].

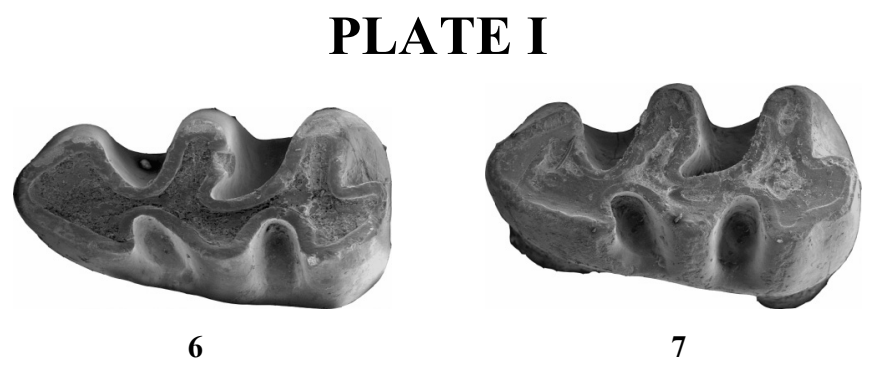

Figs. $(6,7) . \mathrm{m} 1$ dext.

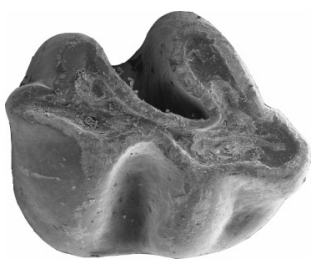

8

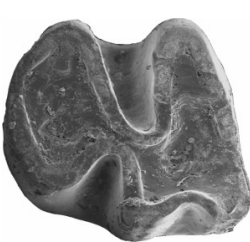

9
Figs. $(8,9) . \mathrm{m} 2 \sin$

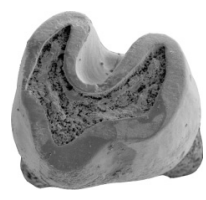

10

Figs. (10). $\mathrm{m} 3$ dext.

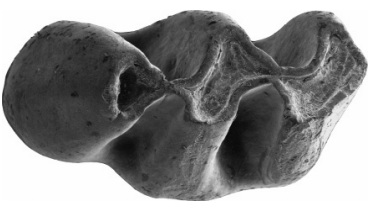

11

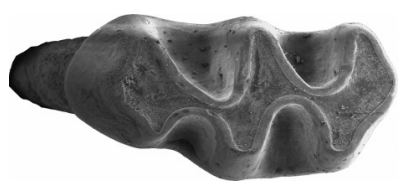

12
Figs. (11, 12). M1 dext.

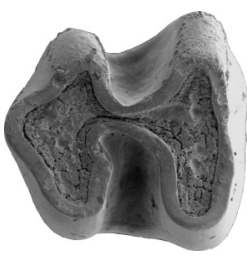

13

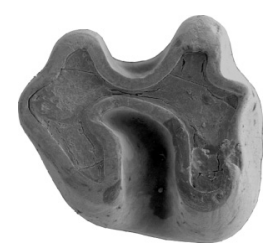

14
Figs. $(13,14)$. $M 2 \sin$.

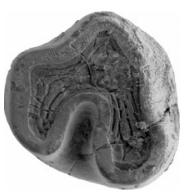

15

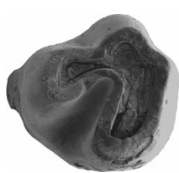

16
Figs. $(15,16) . M 3 \sin$.

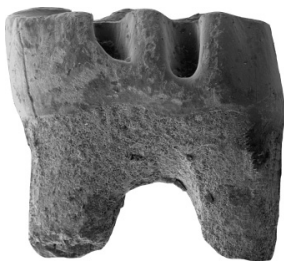

17

Fig. (17). Labial view of $\mathrm{m} 1$ a dext. 


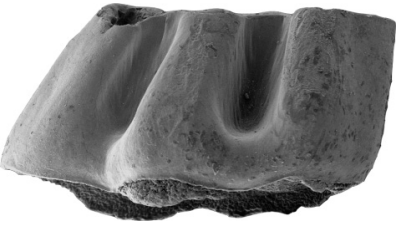

18

Fig. (18). Lingual view of $\mathrm{m} 1$ a dext.

\section{$1 \mathrm{~mm}$.}

\section{All figures X 20}

İğdeli locality is assigned to the Early Pliocene/Early Ruscinian (MN 14) age on the basis of the occurrence of Promimomys insuliferus.

\section{ACKNOWLEDGEMENTS}

I am indebted to my supervisor Engin Ünay (Ankara), for encouragement and providing the material studied in my work. I deeply thanked Hans de Bruijn (Utrecht) who has taken the S.E.M. photographs in the study for his thoughtful review and I am also grateful for Scientific Researches Projects Department of Cumhuriyet University (CUBAP, F-129, 2002).

\section{REFERENCES}

[1] N. M. Sumengen, E. Unay, G. Sarac, H. de Bruijn, I. Terlemez and M. Gurbuz, "New neogene rodent assemblages from Anatolia (Turkey)", Eur. Neogene Mammal Chronol., Nato Sci. Ser. A, vol. 180 , pp. $61-72,1989$.

[2] H. Tong, "Origin and evolution of Gerbillidae (Mammalia, Rodentia) in North Africa", Mem. Soc. Geol. France, vol. 155, pp.1-120, 1989.

[3] S. Sen, "The fauna of rodents of Calta Pliocene (Ankara, Turkey)", Bull. Mus. Natn. Hist. Nat., 465, Sciences de la Terre, vol. 61, pp. 89-172, 1977.

[4] S. Sen, "Rodents and lagomorphs from deposit pliocene Pul-e Charkhi, Kabul Basin, Afghanistan", Bull. Mus. Natn. Hist. Nat., Paris $C$, vol. 1, pp. 33-74, 1983.

[5] H. de Bruijn, "Smaller mammals from the Upper Miocene and Lower Pliocene of the Strimon basin, Greece". Part 1. Rodentia and Lagomorpha. Boll. Soc. Paleontol. Ital., vol. 28, pp. 189-195, 1989.

[6] S. Sen, "Rodents and insectivores from the upper miocene of Molayan, Afghanistan", Palaeontology, 44, vol. 5, pp. 913-932, 2001 .
[7] J. Agustí, "Gerbillides fossils of Western Europe", The rodent of Espace. In: M. Berre, and, L. Guelte, Eds. R. Chabaud, Paris, 1991, pp. 177-182.

[8] W. Wessels, "Gerbillinae from the miocene and pliocene of Europe. Mitteilungen der Bayerischen Staatssammlung fur Palaontologie und historische", Geologie, vol. 38, pp. 187-207, 1998.

[9] W. Wessels, "Family Gerbillidae", In: G. Rossner, K. Heissig, Eds. The Miocene Land Mammals of Europe, Munchen, Pfeil Verlag, 1999, pp. 395-400.

[10] A. I. Sylvestrou, and S. D. Kostopoulos, "Pseudomeriones megistos nov. sp. (Gerbillinae, Mammalia) from the Latest Miocene of Northern Greece and its phylogenetic relationships", Geobios, vol. 40, pp. 833-848, 2007.

[11] S. Sen, "The age of the Molayan mammal locality, Afghanistan", Geobios, vol. 31, pp. 385-391, 1998a.

[12] E. Unay, H. de Bruijn, and G. Sarac, "A preliminary zonation of the continental Neogene of Anatolia based on rodents", In: W. F. Reumer, and W. Wessels, Eds. Distribution and Migration of Tertiary Mammals in Eurasia, A volume in honour of Hans de Bruijn. Deinsea, vol. 10, 2003, pp. 539-547.

[13] F. Suata-Alpaslan, Pseudomeriones latidens Sen, 2001 (Rodentia, Mammalia) from Karaozu, Kalekoy and Dendil (Sivas, Turkey), University of Ankara, Antropoloji, vol. 16, 2004, pp. 17-29.

[14] P. T. de Chardin, "Tertiary mammals of China and Mongolia", Ann. Paleontol., vol. 15, pp. 1-51, 1926

[15] L. D. Brandy, "Rodents muroides of Neogene superieur of Afghanistan. Evolution, biogeography, correlations", Palaeovertebrata, vol. 11, pp. 13-179, 1981.

[16] H. de Bruijn, M. R. Dawson, and P. Mein, "Upper Pliocene Rodentia, Lagomorpha and Insectivora (Mammalia) from the Isle of Rhodes (Greece), I, II and III", Proceedings of the Koninklijke Nederlandse Akademie van Wetenschappen, B, vol. 73, 1970, pp. 535-584.

[17] C. C. Black, L. Krishtalka, and N. Solounias, "Mammalian fossils of Samos and Pikermi, Part 1. The Turolian rodents and insectivores of Samos", Ann. Carnegie Museum, vol. 49, pp. 359$378,1980$.

[18] S. Sen, J. J. Jaeger, N. Dalfes, J. M. Mazin, and H. Bocherens, "Discovery of a small sammal fauna in western Anatolia pliocene", C. R. Acad. Sci. Paris, vol. 309, pp. 1729-1734, 1989.

[19] B. Ferre, "Mammals from deposit of Develi (Manisa, Turkey)", Memoire de DEA de Paleontologie, universite de Montpellier Press, 1990 .

[20] Z. Zhang, "Pliocene micromammal fauna from Ningxian, Gansu province", Proceedings of the Seventh Annual Meeting of the Chinese Society of Vertebrate Paleontology, 1999, pp. 167-177,

[21] F. Suata-Alpaslan, "The Rodentia and Lagomorpha (Mammalia) of the early Pliocene from Anatolia: biochronological, paleogeographical, paleoecological and paleoclimatological implications", $\mathrm{Ph}$. D. thesis, University of Cumhuriyet, Department of Geology, Sivas, Turkey, 2003. 